\title{
The Problem of Dormitory Schools as Human Resources Development for Native Papuan Children, Indonesia
}

\author{
Tuty Sariwulan ${ }^{1}$, Iskandar Agung ${ }^{2}$, Genardi Atmadiredja ${ }^{2}, \&$ Unggul Sudrajat $^{2}$ \\ ${ }^{1}$ Faculty of Economy, State University of Jakarta, Jakarta, Indonesia \\ ${ }^{2}$ Center of Research Policy of Education and Culture, MOEC, Republic of Indonesia \\ Correspondence: Genardi Atmadiredja. E-mail: tuty.wulandari@unj.ac.id; iskandar.agung@kemdikbud.go.id; \\ ominoreg87@gmail.com; unggul.sudrajat@gmail.com
}

\author{
Received: April 15, 2019 \\ Accepted: June 1, 2019 \\ Online Published: June 30, 2019 \\ doi:10.5539/ass.v15n7p28 \\ URL: https://doi.org/10.5539/ass.v15n7p28
}

\begin{abstract}
This paper aims to examine the effect of government policy variables, continuance commitment, school image, and parents' aspirations on dormitory school performance. Data collection is done by distributing questionnaires to teacher respondents, interviews, and focus group discussions. The study found that government policies and continuance commitment had a positive influence on school performance, while the school image variables and the aspirations of parents did not have a positive influence. A more coordinated and synergic operational mechanism is needed between the government (central, provincial, district) and schools to improve dormitory school performance. The government needs to give priority to honorary teachers in recruiting workers with work agreements (PP No. 48/2018), by not implementing a system of employment agreements (contracts), but as non-ASN permanent teachers who get salary / wages in accordance with applicable regulations (recommended based on regional minimum wages), the right to take competency tests and get teacher professional allowances, family health insurance, leave rights, capacity building training, and others.
\end{abstract}

Keywords: human resources, dormitory school, honorarium teacher, government policy, continuance commitment, school image, parent aspiration, school performance

\section{Introduction}

As an archipelago country, Indonesia it consists of 37 provincial regions with diverse geographical conditions and people's lives. This condition is often an obstacle in the implementation of development, one of which is in the field of education. The Papua Province can be said to be the most left behind region in the development of education. Various problems faced in the development of the education sector, starting from the geographical side, which are mostly mountainous regions, limited transportation infrastructure, traditional community life, relatively few population with scattered settlements, and so on.

In the education sector the Papua province records a low Gross Participation Rate (GPR) and Pure Participation Rate (PPR). In addition to the problem of participation of school-age children, in this region face the limitations of school buildings, availability of teachers, learning support facilities, and high dropout rates. In terms of quality of education is still relatively low at all levels of Education that exist. Even though the area is 421,981 $\mathrm{km} 2$ (3.5 times greater than Java Island), Papua province is an area that has very abundant natural resources, such as gold, copper, silver, natural gas, petroleum, coal, and mining, forest wealth, and marine products. In fact, this is where the largest reserves of gold and copper reserves are ranked second in the world. Through this natural wealth, the Papua Province has a large contribution to the income of Indonesia's financial treasury. However, these conditions are very contradictory to the quality of life of the people, where according to the results of the Human Development Index (HDI) Papua is still relatively low and very lagging compared to other regions in Indonesia.

The indigenous Papuans are people from the Melanesian race group consisting of indigenous tribes in the Papua Province and / or people who are accepted and recognized as indigenous Papuans by the indigenous Papuans (Regional Regulation of Papua Province Number 2 of 2013). Most of the indigenous Papuans are scattered in the coastal and inland areas in the enclaves of small villages, divided into five indigenous territories (Mamta, Saireri, Animha, La Pago, and Mee Pago). Since a few years ago it was decided by the government to organize 
dormitory schools as an alternative solution for education development in Papua. Furthermore regulations concerning dormitory schools are regulated in the Regional Regulation of Papua Province Number 5 of 2006 which opens opportunities to develop education in accordance with the conditions and capacities possessed by the district. One of the articles in the regional regulation also states that the district can organize dormitory schools to improve the quality of Papuan children with funding from government and private sectors.

In fact, the implementation of dormitory schools in Papua Province still contains various weaknesses. Field observations in a number of districts in Papua province tend to show that dormitory schools built by the government have not functioned well. One dormitory school in Mimika Regency that organizes education from elementary school (SD) to high school (SMA), for example, currently has a dormitory building that is not feasible, even endangering residents (students). This school also facing lacks of teachers and is filled with honorarium status. Housing for teachers is not occupied, and some are severely damaged. In other districts, such as Keerom and Nabire, government-built dormitories do not function because they do not have native Papuan students. Some dormitory buildings in Nabire even in destroyed conditions, are no longer shaped. Hostels that are still suitable for use by teachers and students who are not from Papua. In one of the State High Schools in Nabire, for example, it was inhabited by four female students from Toraja Land. The same case was experienced in another school, the dormitory was occupied by the teacher's family and a student from Bugis. One other dormitory school in Nabire which was originally to educate elementary school teachers was changed to public secondary school (Utama et al., 2017; Sudrajat et al., 2018).

It is interesting to study dormitory schools in Papua province, because this educational institution is an effort to develop Papuan human resources as a cultural leap from primitive life to the modern world. The children of Papua who were originally isolated and scattered on the coast and inland with life dependent on nature, must be uprooted to carry out education in dormitory schools. The students in dormitory schools are thought to be easily influenced by external influences, especially from those who disseminate separatist movement activities, such as alumnie, Papuan students from a number of universities, and groups that call the Free Papua Organization (by the Indonesian government called the Armed Criminal Group).

The failure of education in dormitory schools is thought to bring unachieved efforts to develop indigenous Papuan human resources. The indications of failure were strengthened in the field, caused by various reasons that showed weakness. On that basis it needs to be studied, why is the management of dormitory schools in Papua not running optimally, even though the government has issued relatively large funds to build this educational institution?

This paper is part of the results of research on dormitory schools in Papua Province. The paper examines the effect of several factors on school dormitory performance. The use of influence factors is based on field observations and studies conducted by Purwoko et al. (2015), Perdana et al. (2017); Utama et al. (2017); and Sudrajat et al. (2018). The factors considered here are government policy, continuance commitment, organizational image, and the aspirations of parents who are considered to affect the performance of dormitory schools. The factors of government policy, sustainability commitment, organizational image, and aspirations of parents are exogenous latent variables that are considered to affect the endogenous latent variables of dormitory school performance. From the results of this study it is expected that conclusions can be obtained to find the right strategy to improve the implementation of education in dormitory schools, especially in the province of Papua.

\section{Literature Review}

\subsection{Education Development in Indonesia}

Development is planned or intentional change effort, where new ideas are introduced and communicated into a social system so that various aspects of life get better (Foster, 1970). Through development, the introduction of new ideas is usually accompanied by methods, approaches and certain techniques in order to be accepted and adopted by the recipient's social system (recipient) and perceived benefits for improving life.

In the context of national development as an effort to change, one of the important elements to support its success is human development. Even research shows that human development has a threefold positive impact on economic growth compared to production equipment (Suryadi, 2012). On that basis, especially in the face of increasingly globalized human life, various countries competed to direct the attention and national budget to investment in the development of human resources. The life of an open and unlimited world community brings increasingly fierce competition. That is the main reason for each country to prepare high-quality human resources to be able to use it to improve their welfare. 
Education is considered as a determining variable to form quality human resources and win in competition. Many countries give high commitment to efforts to develop education, one of which is shown through the act of allocating substantial funds for educational purposes, namely between 20-40 percent of their state expenditure (Lazear, 2002). China, South Korea, and Singapore by providing sufficiently large budgets for the education sector, have brought rapid progress towards economic growth and the welfare of their people (Anwar, 2014). In Indonesia, for several years, it has allocated a budget of at least 20 percent of the state expenditure for the development of education. In 2015 for example, Indonesia has allocated a budget for education reaching 20.59 percent of total state expenditure (Azhari, 2014).

\subsection{Development of Human Resources in the Province of Papua}

Development of human resources for indigenous Papuan children, get special attention from the government. The development of the education sector in Papua requires specificity, given the unique socio-cultural characteristics, physical environment, settlement patterns, and others. The Papuan people who generally live in small groups in rural areas need different handling in the implementation of education, both related to the provision of facilities, infrastructure, reachability, and so on.

Since several years ago, the idea emerged to provide education for the people of Papua through the application of the dormitory school concept. Dormitory schools are considered a breakthrough so that native Papuan children can undergo the learning process in certain learning buildings. Bull (2001) quotes the Oxford Dictionary as saying that dormitory schools are educational institutions where students learn and live together during learning activities. Maksudin (2006) defines that dormitory schools are places of learning and student residence; study in total in the school environment. Dormitory schools are educational institutions where students not only study but also live and live together in the institution. Dormitory schools combine living at home, being transferred to a school institution, where in school various living facilities are provided such as: bedrooms, living rooms, study rooms and sports, library, and art venues.

Through the implementation of dormitory schools, freeing all forms of obligation to pay expenses by parents, and students are expected to be able to learn more to concentrate, interact directly with teachers, controlled activities, and build independence. The implication is that dormitory schools are expected to be able to provide optimal cognitive, affective, and psychomotor education for Papuan students.

\subsection{Type of Dormitory School in Papua}

There are three types of dormitory schools seen from the side of the function of student residence, namely: (1) the type of all dormitory school, where all students live in a dormitory / school; (2) day school boarding, where some students live in boarding and some outside the boarding; and (3) day boarding, where the majority of students live outside the boarding and others live in the boarding (Nurkhamid, 2015). Dormitory schools in the province of Papua are more like type numbers 1 and 2. In terms of the implementation of education, there are two types of dormitory schools in the Papua province: (1) conducting integrated education from elementary school (SD), junior high school (SMP), and senior high school (SMA) levels; and (2) holding only certain levels of education by joining conventional schools (for example: in conventional high schools). In Papua province, the first type of example was organized by the Education Center Dormitory school in Mimika Regency, Dormitory school in Keroom District, and Dormitory school in Yapen District; the second example was held by a number of public high schools in Nabire and Jayapura districts.

The pattern of dormitory schools is one of the gift of the education rights of native Papuan children from coastal and inland areas which have tended to be traditional and not yet reached by educational facilities. According to Tahya (2009), in dormitory schools student activities will be guided, there will be closeness between teacher and students, student problems will be known and resolved soon, teachers and students can remind each other about patience, truth, compassion, and planting honesty values, tolerance, responsibility, obedience and independence.

\subsection{Research Variable}

As the implementation of education in a school institution, it is ensured that dormitory schools in the Papua province cover the complexity of the variables that influenced, starting from the input elements (policies, students, management, teachers, curriculum, education costs, social environment, etc.), teaching and learning processes, and student learning output (Usman, 2014). A study conducted by Bakti et al. (2017), and Sudrajat et al. (2018) in dormitory schools in Papua showed that there were still obstacles related to the issues of policy, teachers, school image, and aspirations of parents of students. In terms of policy, it is related to the coordination and division of labor between the provincial and district governments, which is raised problems in terms of funding the renovation of buildings and others. From the teacher's side it is still dominated by the existence of an 
Honorarium teacher who can at any time carry out work shifts and harm the learning process. In terms of the image of the school, these educational institutions have not focused on quality-oriented performance. In terms of parents, parents have low aspirations and participation in children's education. All of this is thought to have an effect on the performance of dormitory schools. On this basis this paper focuses on the variables of school performance, government policy, continuance commitment, school image, parents' aspirations, and student learning outcomes.

\subsection{School Performance}

The success or failure of dormitory schools in Papua is largely determined by the school's performance. School performance as an organization can be interpreted as the results achieved by these educational institutions (see: Robbins, 1997; Sucipto, 1997; Bacal, 2004). The performance of the school itself can be assessed through indicators of quantity of work, quality of work, job knowledge; creativeness; cooperation, dependability, and work integrity (Gomes, 1995).

The performance of dormitory schools in the Papua province is influenced by the internal and external factors of the school. These factors also determine the school's performance in achieving the goals and results achieved. Among these factors that will be the focus of the study here are government policy, continuance commitment, school image, and parents' aspirations. This paper wants to show how these factors affect the performance of dormitory schools.

\subsection{Government Policy}

In general, policy can be interpreted as a set of concepts and principles that become lines and the basis of plans in the implementation of work, leadership, and ways of acting (about orders, organizations, etc.). Friedrich (1969) argues, policy is a set of actions / activities proposed by a person, group or government in overcoming obstacles or problems in a particular environment. Anderson (1998) interpreted as a series of actions that have certain goals that must be followed and carried out by the perpetrators to solve a problem.

Associated with dormitory school policies, at least includes three important aspects, namely regulation, division of labor, and coordination in its operations. In terms of regulations, the construction of dormitory schools in the Papua province is stated in Regional Regulation No.5 / 2006. In terms of the division of labor related to the delegation of authority to manage education as stipulated in Law No. 32/2004 as a revision of Law No. 22/1999 concerning Regional Government, where SD and SMP are the authority of the district government (Regency / City) and high school authorities of the provincial government. This division of labor concerns all matters relating to the implementation of education from infrastructure, school principals, education funds, teachers, and so on. The implication is that there is dualism in the management of education in integrated dormitory schools in the Papua province in accordance with the authority of the provincial and district governments. As a logical consequence, a synergic coordination between institutions is needed regarding the implementation of dormitory schools. In the case of one of the dormitory buildings that have been badly damaged for years, it is not yet known who is authorized and responsible for repairing it.

Harmonization and synergy of policies with their implementation are thought to affect the performance of dormitory schools in the Papua province. Various studies show a relationship between policy and organizational performance. Sukendro and Pujiharjanto (2012) suggest that there is an influence between dividend policy by the government and the performance of business organizations. Suryana (2016) shows the influence of policies on employee performance in the city of Banjar. In the field of Education, Hidayat (2013) showed a positive relationship between teacher certification policies to improve learning performance.

\subsection{Continuance Commitment}

Continuance commitment is a factor that is thought to have an influence on dormitory school performance. This factor is one aspect of the organizational commitment of employees, especially teachers, in dormitory schools for their workplaces. Colquitt (2015), Luthans (2011), Schermerhorn Jr. (2010), Gibson et al. (2015) concluded that organizational commitment is a condition of how many employees attach themselves to the organization and adhere to organizational goals, and hope to maintain membership in the organization. Furthermore Cooper (2011) divides organizational commitment into three types, namely: affective commitment, continuance commitment, and normative commitment.

Especially continuance commitment refers to the views of employees about work in the workplace organization that encourages morale, hope, and the desire to survive or leave the organization. The persistence tendency is usually because employees consider their sustainability to be a necessity, otherwise they will lose if they leave it. According to Allen and Meyer (1984), employees continue to work because they feel more benefits received. 
The strength of the continuation commitment tends to bring someone to continue working, on the contrary the weakness of commitment will bring employees to change jobs.

Continuance commitment is thought to be a factor that influences the performance of an organization, especially workers. The study was conducted by Nurandini and Lataruva (2014), one of which showed the influence of continuance commitment on employee performance. The same findings were produced by Nurbiyati (2014), Akbar et al. (2017), and Pane and Fatmawati (2017) in their study. Strictly speaking, the performance of an organization is determined by employee organizational commitment, one of which is continuance commitment. Within the scope of the discussion of this paper, continuance commitment refers to teacher status in influencing school performance.

\subsection{School Image}

Image is an abstract and intangible term, but it can be felt in the form of someone's assessment of an organization. Simply stated, the image is an understanding of the impression that arises because of an understanding of an organization. Tall and Vinner (1981) reveal that the image as a collection of mental images along with processes and associated characteristics with the concept that is in the mind of the individual. Ardianto and Soemirat (2010) argue that the image is an impression or public image of the organization. Kotler (2011) argues, image is a public perception of an organization and the results / products achieved. Lievens (2017) argues that the organizational image of refers... as people's loose structures of knowledge and beliefs about an organization.

The public captures various information about an organization, and the results achieved in the image of the organization. Positive organizational images will encourage positive perceptions, and vice versa. Furthermore, a positive public image will provide benefits, such as a positive response to the organization and products, awareness of the importance of the existence of the organization, improving communication, and so on. For organizations, a positive image can increase awareness about the organization, improve performance to achieve quality results, public satisfaction as users of service / product organizations, and others. Various studies show a positive influence between organizational image on organizational performance. Namubiru et al. (2014) showed that there was a significant relationship between corporate image and organizational performance. The same findings are shown by Küçüksüleymanoglu (2017), and Ferryanto and Hatane (2015). In the discussion about dormitory schools here the provisional estimates of school image have an influence on the performance schools.

\subsection{Parents' Aspirations}

Papua Province Central Bureau of Statistics (BPS) noted, in the 2016/2017 academic year there were 408,762 elementary school students, 120.2260 junior high school students, 58,152 high school students. Most of the students came from other ethnic families (Java, Bugis, Toraja, Maluku, East Nusa Tenggara, and others), who came to this area because they joined the transmigration program, worked in the mining sector, traders, illegal gold miners, and so on. Conversely, only a relatively small number of students are native children of the region. That is also accompanied by a situation of high dropout rates from elementary and junior high school students, especially in coastal and inland areas (Unicef, 2016). Some of the above students and students who have dropped out of school, come from dormitory schools.

Allegations while the performance of dormitory schools was also influenced by the aspirations of parents. Nurwati (2008), Irwana (2011), Bunu, (2014), Hulukati (2015), Dewi et al. (2014), Kamsihyati et al. (2016), and Sugiyanto (2017), for example, show the influence of family aspirations on the sustainability of education or student dropouts. These aspirations can arise from a sense of satisfaction or dissatisfaction among students' parents with schools, so they tend to assess the importance or lack of importance of their children's education. Kotter (2011) in looking at the relationship between a sense of satisfaction and performance suggests, satisfaction arises as a feeling of pleasure or disappointment someone towards the performance of an organization. Kusumasitta (2014) suggests satisfaction is a function of performance and expectations. If the performance is below expectations, the user is not satisfied, otherwise if the performance meets expectations, the user will be satisfied. Some studies show the influence of consumer satisfaction on organizational performance, as done by Santhi and Hartati (2017), Prakarsa and Tarigan (2016), and Saufa and Maryati (2017).

\subsection{Student Learning Results}

The performance of dormitory schools is an effort to develop human resources for indigenous Papuans which will be reflected through learning outcomes. In general, learning outcomes can be said to be changes in behavior and abilities of students achieved due to planned or intentional efforts. Kingsley (1951) divides three kinds of teaching and learning outcomes, namely skills and habits, knowledge and direction, attitudes and ideals. In the development of the current global era, the demand for the implementation of education must be able to produce 
output of students who master science and technology; literacy reading - writing - counting, creative, critical thinking, being able to communicate to convey thoughts / ideas, able to collaborate in solving increasingly complex problems; and information and communication technology literacy (Pearlman, 2006; ISTE, 2008; Agung, 2017).

Various studies show the relationship of influence between school performance and student learning outcomes. Zulfahmi et al. (2017) showed a correlation between school performance and student achievement. Or Manullang (2017) in his research found that school performance reflected by teacher performance had a significant influence on student learning results. In line with that, the temporary suspicion is that there is an influence between the performance of dormitory schools and the students' learning results.

\section{Methodology}

\subsection{Population and Sample}

This paper is part of the results of research on 12 dormitory schools in the province of Papua (District Mimika, District Nabire, Kota Jayapura, District Jayapura, District Keroom). Seven state-owned schools and five private schools. From sample schools, one school organizes an integrated education system for SD - SMP - SMA; two elementary - junior high schools; two junior high school to high school; and other types of schools complement conventional schools (junior high or high school). The study population was all teachers in the sample dormitory schools, with samples drawn from each school through a random technique. Study samples were 120 respondents who would answer questions in the questionnaire. Implicit, research is more of a teacher's perception of seeing dormitory schools through answers to questions in the questionnaire.

\subsection{Type and Analysis Data}

Primary data is obtained from distributing questionnaires to the respondent's teacher, coupled with secondary data in the form of information from interviews, focus group discussions, and relevant documentation. Especially the questionnaire was developed by the research team which included the variables studied. Before the questionnaire was distributed, validity and reliability were tested using the product moment test from Pearson and Cronbach Alpha with the help of the SPSS 24.0 version of the program. The minimum validity criteria for the validity test is $=0.361$, and the reliability test is $\geq 0.6$ (Soegiyono, 2010). The test results show that most items in the research statement or question are proven valid and reliable, so that they meet the requirements that will be applied.

Study analysis using Structural Equation Modeling (SEM) with the help of Lisrel 8.80 program. SEM can be done, because the number of samples meets the minimum requirements of 100 respondents (Kusnendi, 2009; Haryono, 2013).

\subsection{Theoretical Model}

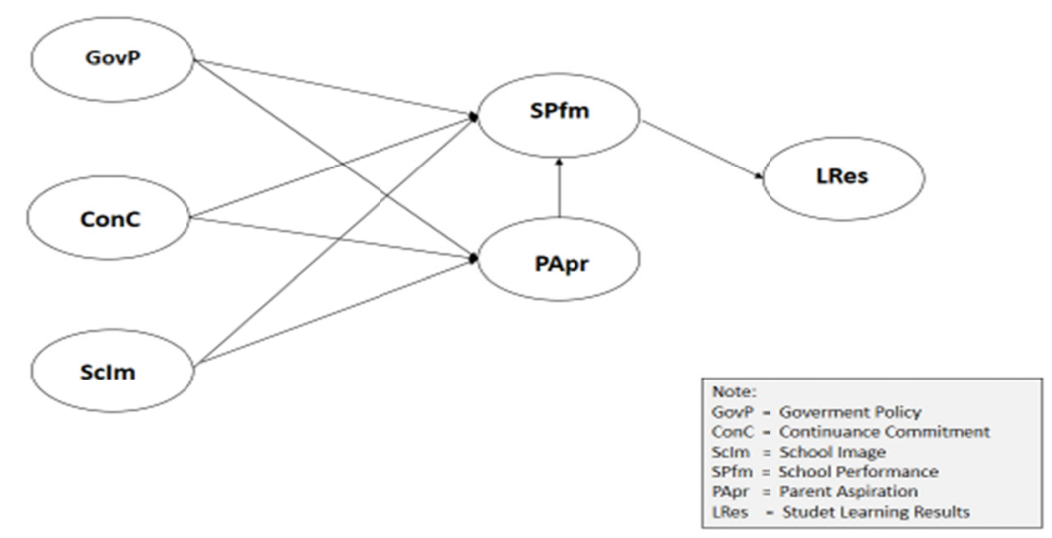

\subsection{Hypothesis}

- There is an influence of Government Policy on School Performance

- There is the influence of Continuance Commitment Teachers on School Performance

- There is an influence of School Image on School Performance 
- There is an influence of Government Policy on Parents' Aspirations

- There is the influence of Continuance Commitment Teachers on Parents' Aspirations

- There is an influence of School Image on Parents' Aspirations

- There is an influence of Parents' Aspirations on School Performance

- There is an influence of School Performance on Student Learning Outcomes

\section{Findings}

\subsection{Respondent Description}

Based on the results of questionnaires obtained the number of respondents consisting of 78 permanent status teachers (ASN employees) and 42 teachers with honorarium status. Most (66.67\%) were male teachers, and the remaining 33.33\% were female teachers. All respondents came from Javanese, Bugis, Makassar, Toraja, Maluku, Ambon, and others. For permanent teachers in the State Civil Apparatus (ASN), working in dormitory schools is due to placement by the local government, while the honorarium teacher is recruited by the school.

Table 1. Number of research respondents by status and gender

\begin{tabular}{|c|c|c|c|c|c|c|c|}
\hline \multirow{2}{*}{ No. } & \multirow{2}{*}{ Districts } & \multicolumn{3}{|c|}{ Teacher Status } & \multicolumn{3}{|c|}{ Gender } \\
\hline & & Permanent & Honorarium & Total & Male & Female & Total \\
\hline 1. & Mimika District & $18(15,00)$ & $12(10,00)$ & $30(25,00)$ & $22(18,33)$ & $8(6,67)$ & $30(25,00)$ \\
\hline 2. & Nabire District & $18(15,00)$ & $8(6,67)$ & $26(21,67)$ & $16(13,33)$ & $10(8,37)$ & $26(23,67)$ \\
\hline 3. & Jayapura City & $24(20,00)$ & $10(8,33)$ & $34(28,33)$ & $18(15,00)$ & $16(13,33)$ & $34(28,33)$ \\
\hline 4. & Jayapura District & $10(8,33)$ & $7(5,83)$ & $17(14,16)$ & $11(9,16)$ & $6(6,00)$ & $17(14,16)$ \\
\hline \multirow[t]{2}{*}{5.} & Keerom District & $8(6,67)$ & $5(4,17)$ & $13(10,84)$ & $8(5,84)$ & $5(5,00)$ & $13(10,84)$ \\
\hline & Total & $78(65,0)$ & $42(35,00)$ & $1201000)$ & $80(66,67)$ & $40(33,33)$ & $120(100,00)$ \\
\hline
\end{tabular}

\subsection{CFA Results}

\subsubsection{Test of Validity}

Latan (2012) suggested that Confirmatory Factor Analysis (CFA) was conducted to test the dimensionality of a construct or variable. CFA needs to be implemented as a test of validity and reliability to determine whether indicator variables really form the latent variables studied (Haryono, 2013). Based on that validity test is done to find out whether the question item meets the standardization value of the factor. For the value of the standard loading factor greater than 0.5 , the question item is said to be valid (Ghozali, 2011). Table 2 shows, all items in the statement or indicator in this study are valid, because they have a loading value greater than 0.5 .

Table 2. Results of CFA Validity

\begin{tabular}{cccc}
\hline Variables & Indicators & loading factor & Conclusion \\
\hline \multirow{3}{*}{ School Performance (ETA1) } & X1 & 0,83 & Valid \\
& X2 & 0,84 & Valid \\
& X3 & 0,70 & Valid \\
Goverment Policy (KSI1) & X4 & 0,75 & Valid \\
& X5 & 0,69 & Valid \\
Continuance Commitment (KSI2) & X6 & 0,63 & Valid \\
& X7 & 0,69 & Valid \\
X8 & X9 & 0,72 & Valid \\
School Image (KSI3) & X10 & 0,66 & Valid \\
& X11 & 0,72 & Valid \\
& X12 & 0,65 & Valid \\
Parent's Aspirations (ETA2) & X13 & 0,72 & Valid \\
& X14 & 0,63 & Valid \\
& X15 & 0,69 & Valid \\
\hline
\end{tabular}




\begin{tabular}{llll}
\hline & X16 & Valid \\
Student Learning Results (ETA3) & X17 & 0,58 & Valid \\
& X18 & 0,69 & Valid \\
& X19 & 0,78 & Valid \\
\hline
\end{tabular}

\subsubsection{Goodness of Fit Test}

Structural model analysis in SEM begins with testing the suitability of the overall model which is seen based on indicators of Goodness-of-Fit Index (GFI) statistics from LISREL output (Haryono, 2013). The results of the GOF test can be seen in table 3 .

Table 3. GOF Test Results

\begin{tabular}{cccc}
\hline Size Degree of Match & Value & Acceptable level of compatibility & Conclusion \\
\hline Goodness of Fit Indices (GFI) & 0.91 & GFI $\geq 0,9$ & Good Fit \\
Root Mean Square Error of Approximation (RMSEA) & 0.062 & RMSEA $\leq 0,08$ (good fit) & Good Fit \\
Normed Fit Index (NFI) & 0.94 & NFI $>0,90$ & Good Fit \\
Adjusted GFI (AGFI) & 0.94 & AGFI $\geq 0,90$ & Good Fit \\
Comparative Fit Index (CFI) & 0.98 & CFI $>0,90$ & Good Fit \\
Incremental Fit Index (IFI) & 0.98 & IFI $>0,90$ & Good Fit \\
Relative Fit Index (RFI) & 0.93 & RFI $>0,90$ & Good Fit \\
\hline
\end{tabular}

On the basis of the GOF test it is known that RMSEA is smaller than 0.08 so that it is said to be good fit. Test results of CFI, IFI, NFI, and RFI meet the suitability level of the model with each value greater than 0.90 , which means good fit data. Similar results are shown by the results of the GFI and AGFI tests which show good fit data because the value is greater than 0.90 .

\subsubsection{Structural Model Results}

Standardized Solution

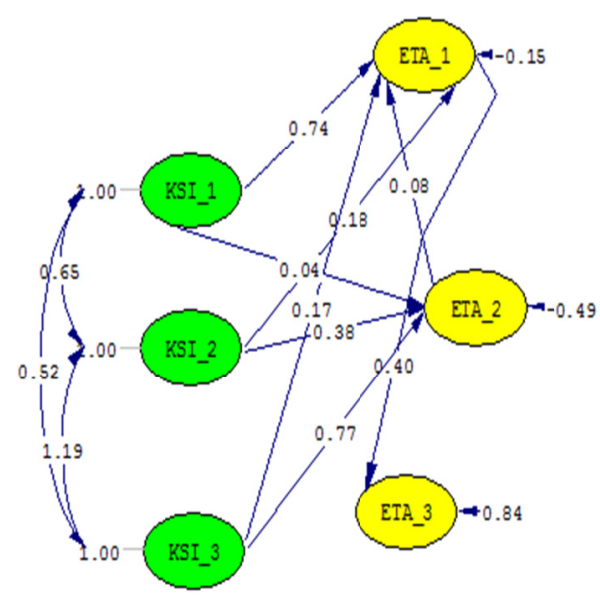

T-Value

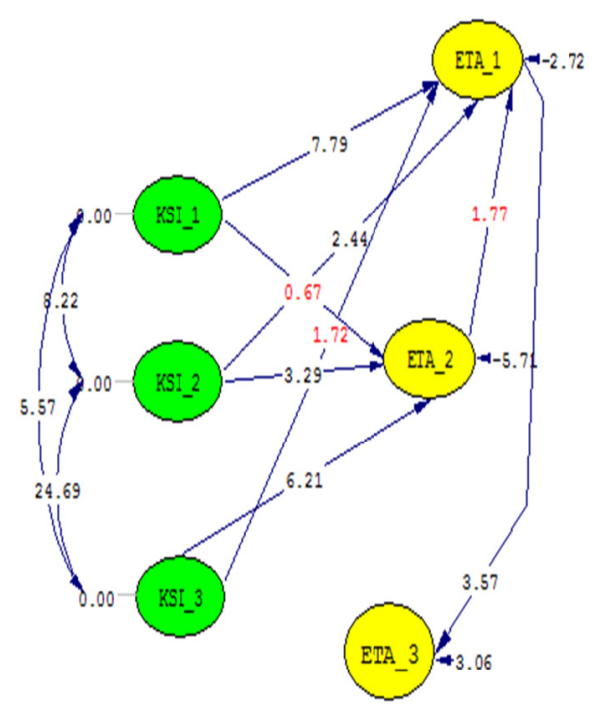

Chi-Square $=205.83, \mathrm{df}=141, \mathrm{P}-\mathrm{value}=0.00030, \mathrm{RMSEA}=0.062$

Chi-Square $=205.83, \mathrm{df}=141, \mathrm{p}-\mathrm{value}=0.00030, \mathrm{RMSEA}=0.062$

\subsubsection{Hypothesis Testing Results}

Hypothesis testing is done by looking at the critical value (CR) at a confidence level of $95 \%$ or a $5 \%$ error. The CR value received is 1.96 (Hair et al., 2006). Table 4 below shows, from the eight hypotheses proposed only five hypotheses were accepted by obtaining a $t$ value greater than 1.96 , three other hypotheses were rejected. 
Table 4. Hypothesis Test Result

\begin{tabular}{|c|c|c|c|c|}
\hline No. & Hypothesis & Loading & T-Value & Conclusion \\
\hline 1. & GovP (KSI1) has a positive $(+)$ influence on SPfm (ETA1) & 0,74 & 7,79 & hypotheses are accepted \\
\hline 2. & ConC (KSI2) has a positive $(+)$ influence on SPfm (ETA1) & 0,18 & 2,44 & hypotheses are accepted \\
\hline 3. & $\begin{array}{l}\text { ScIm (KSI3) does not have positive }(+) \text { influence on SPfm } \\
\text { (ETA1) }\end{array}$ & 0,17 & 1,72 & $\begin{array}{l}\text { hypotheses are not } \\
\text { accessed }\end{array}$ \\
\hline 4. & $\begin{array}{l}\text { PApr (ETA2) does not have positive }(+) \text { influence on SPfm } \\
\text { (ETA1) }\end{array}$ & 0,08 & 1,77 & $\begin{array}{l}\text { hypotheses are not } \\
\text { accessed }\end{array}$ \\
\hline 5. & $\begin{array}{l}\text { GovP (KSI1) ) does not have positive }(+) \text { influence on PApr } \\
\text { (ETA2) }\end{array}$ & 0,04 & 0,67 & $\begin{array}{l}\text { hypotheses are not } \\
\text { accessed }\end{array}$ \\
\hline 6. & ConC (KSI2) has a positive $(+)$ influence on PApr (ETA2) & 0,38 & 3,29 & hypotheses are accepted \\
\hline 7. & ScIm (KSI3) has a positive $(+)$ influence on PApr (KTA2) & 0,77 & 6,21 & hypotheses are accepted \\
\hline 8. & SPfm (ETA1) has a positive $(+)$ influence on LRes (ETA3) & 0,40 & 3,57 & hypotheses are accepted \\
\hline
\end{tabular}

\section{Discussion}

\subsection{Government Policy Toward School Performance}

The positive influence of government policy variables (KSI1) on school performance variables (ETA1) can be understood, because of the school's dependence on learning support facilities and funding from the government (central, provincial, district). According to some school principals interviewed, the implementation of education was not enough with the physical construction of schools and the fulfillment of other equipment (beds, study tables, wardrobes, etc.), but also other aspects, especially routine funds for the interests of school operations, student activities, daily food needs of students, and so on. Dependence on government budgets is faced by public schools because they provide free education, in contrast to private status schools that can attract certain funds from parents of students for the education of their children.

In state dormitory schools, due to the absence of allocation of funds from the provincial and / or district governments to pay for irregular teacher fees, the school must take teacher salaries from special allocation funds (DAK) and school operational assistance (BOS) programs. In both programs there was no allocation of funds for teacher honoraria, but the school was forced to do so to meet the shortage of teachers in certain subjects. This shortfall can be caused by the insufficient number of teachers from the beginning, but it can also be caused by the number of teachers entering retirement.

Implicitly, a budget that is too late for students' food needs, for example, will be a serious problem for dormitory schools. Likewise, the delay in decreasing funds for the DAK / BOS program will disrupt teaching and learning activities, especially in paying teacher salaries. At present the problem in a number of dormitory schools is student dormitory buildings that have suffered severe damage and endanger students. This situation has been going on for several years, but there are no signs of renovation. Within the scope of repairs to this dormitory building, the law that divides the management of primary and junior secondary education is under the authority of the district government and the level of secondary schools with the authority of the provincial government, still creating coordination problems from both.

Explicitly, the implementation of policies issued regarding the administration of dormitory schools affected the performance of the educational institutions themselves. Dunn (2000), Kraft and Furlong (2017) suggest that theoretical policies require practical implementation. Policy implementation determines whether an organization will succeed or fail to achieve the objectives outlined in the previous policy. Therefore implementation dormitory school policies are closely related to their implementation to achieve directed targets.

In the context of dormitory schools in the province of Papua, the policy is related to the authority and administrative capacity of each government (central, provincial, and regional) to take various actions, starting from the determination of goals and objectives, analysis of formulation and policy strategies, decision making, planning, programming, drilling, mobilizing people, carrying out operational activities, monitoring and evaluating.

\subsection{Continuance Commitment Toward School Performance}

The positive influence of the continuation commitment variable on school performance variables is related to the 
teacher's desire to stay or not work in a dormitory school. There is a tendency for teachers in dormitory schools to change jobs when they get a new place to work. This desire is not only expressed by honorary teachers, but also permanent teachers (ASN). In private dormitory schools motivated by spiritual religion, the continuing commitment to keep working is quite high.

The reason stated by teachers who want to change jobs is that teaching in dormitory schools is considered more severe than in conventional schools. The teacher must work hard to teach students from the interior, given the relatively low average ability. In fact, it is often found that students who have graduated from elementary school from the interior who continue to junior high school cannot yet read, so teachers need to provide special treatment to receive subject matter. Another case is the number of students who go home for a long time, but they do not want to go back to school to continue their education, so the teacher must persuade him to go back to school.

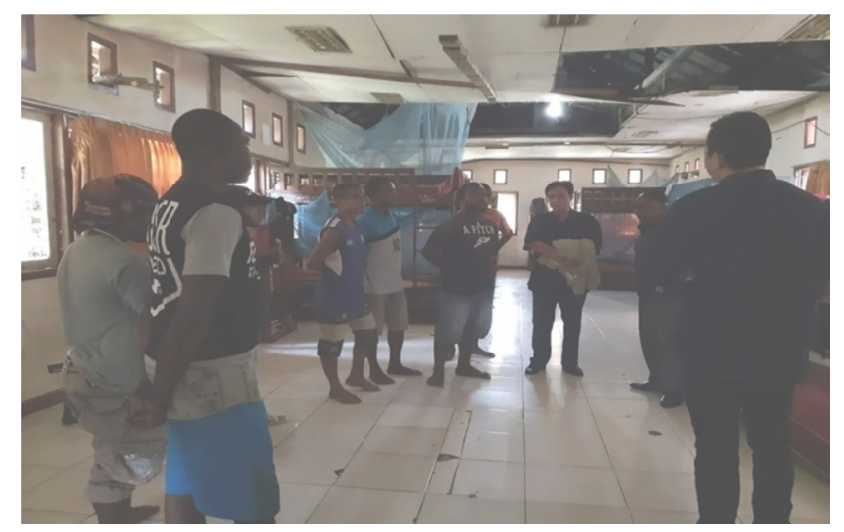

One of the dormitory buildings in Papua province has been severely damaged and endangered residents, when will it be renovated?

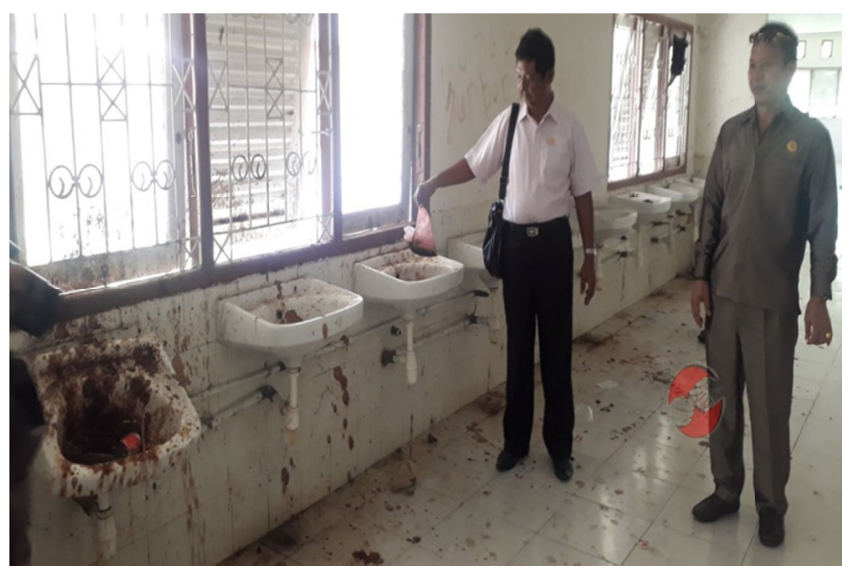

The desire to move to work was further expressed by honorary teachers. So far they continue to carry out their duties, even though the salary / wages are relatively small, only around Rp. 300,000 - Rp. 600,000 per month ( $\$ 1$ USD = Rp. 14,000), because expectations are accepted as ASN employees. However, the government has suspended receipt of ASN employees for several years, leading to a pessimistic attitude from honorary teachers. In the past two years the recruitment of ASN employees was indeed opened by the government, but in small numbers.

In the case of dormitory schools in Papua, the motivation of employees who want to resign from work is a job that is considered to provide less opportunities for career advancement, especially hopes of being appointed as permanent teachers of civil servants, plus a low salary, etc. This is in line with the opinion of Mathis and Jakcson (2006), that small career opportunities, less competitive salaries and benefits, differences in performance rewards, workloads and responsibilities, are some of the reasons an employee wants to resign from his workplace. A similar opinion was expressed by Mc'Kenna (2002) regarding the reasons for employees to resign, including: less attractive work challenges; difficult career development, salary / wages that are considered unfair, 
unfavorable working relationships, and a weak work environment or culture.

\subsection{School Image Toward School Performance}

School image variables do not have a positive effect on dormitory school performance. This is understandable, because dormitory schools have not placed aspects of the school's image on student acceptance. The principle of organizing dormitory schools is the fulfillment of the right to education and increased participation of Papuan children from coastal and inland areas. Education is one of the strategies to develop Papuan human resources, so that it can participate in the regional development process and improve the welfare of family life.

Explicitly, the focus of dormitory schools has not been oriented towards achieving the results of quality education, providing good education services, improving school brands, etc., but prioritizing preventing dropouts, successfully completing education, and increasing education participation of Papuan children. Efforts to build a school image by improving the quality and education services to attract intelligent students, such as those conducted by schools in other parts of Indonesia, have not been seen in dormitory schools in Papua. Especially when faced with the availability of teachers who are still incomplete (the majority are still honorary teachers), and the lack of teaching and learning facilities, it is difficult for schools to emphasize the image of the school as a quality educational

Kotler (2011) suggest that image is a perception of an organization or product. Positive organizational or product images will encourage positive perceptions of the public, so that it will bring benefits to the organization, product use, and public loyalty (users). According to Gronroos (1990), there are four roles of organizational image, namely: the role of telling hope, the role of filters that influence perceptions of organizational activities, the role of fulfilling the expectations of users, and the role of management. Based on that, improving the image of the organization and products related to quality requires good organizational performance. Internal actions that improve organizational performance are needed if the image wants to be improved, because the image is formed from the organization carrying out its operational activities that have a main foundation for the service aspect.

Based the above opinion, dormitory schools in Papua province have not emphasized from the point of producing quality products and services, so they still ignore aspects of improving the image of the school. Emphasis is on efforts to maintain and increase the education participation of Papuan children. Moreover, schools face various shortcomings of educational instruments in terms of dormitory buildings, educational facilities, teachers, and so on. It is not surprising that the research respondents gave a negative perception of the role of the image of this school in the performance of dormitory schools.

\subsection{Parent Aspiration Toward School Performance}

Parents' aspirations are variables that have no positive influence on school performance. From the field, it was found that the attention of parents from native Papuan children from coastal and inland areas to education was very low. Parents are more likely to involve children in family economic activities, such as helping gardening / farming, looking for tubers, scraping sago, caring for pets, catching fish in rivers, and others. Children function as production units to support daily family life. Entering children into dormitory schools directly reduces family consumption needs.

The government has issued a policy to implement free education for the primary and junior secondary levels and prohibits collecting fees from parents. In dormitory schools run by the government, each level of education (SD SMA) is funded by the government (province and district). Unless dormitory schools (private) are still allowed to ask for funds from parents, both for the initial registration of school entry and monthly fees for children's education. However, the source of the budget for private dormitory schools is also obtained from foundations which are usually domiciled at home and abroad. In this dormitory school, children's participation in schools is more driven by traditional leaders and / or religion (missionaries), not parents' encouragement. It is not surprising that research respondents tended to provide unpleasant answers to the influence of parents' aspirations on boarding school performance.

From the field it was found that parents whose children were educated in primary and junior secondary schools in dormitory schools often did not know about the rules of compulsory education. Parents do not consider children's education as a mandate of the state constitution, but are considered to originate from school. In fact, some children who receive education funding through a smart Indonesian program (PIP) are better understood to come from schools, not the government. Not surprisingly, government policy does not have a positive influence on the aspirations of parents.

In the input-process-output theory, it is stated that parental participation also supports the success and failure of 
the implementation of education in schools (Usman, 2014). In addition to the family's socio-economic background, parents' aspirations often determine the child's success in completing their education. Hurlock (1999) argues that aspiration is the desire for something higher with progress as its goal. Hong and Ho (2005) found that parents' aspirations largely determined children's continuity and academic performance (Sehee Hong \& Hsiu-Zo Ho, 2005). Head (2017) shows that the understanding of most parents about the importance of education in the villages studied is still very minimal. Parents often sacrifice their children's education for children working in fields that are considered more important than their children's education. This description reinforces the results of the analysis of the absence of a relationship between the aspirations of parents and the performance of dormitory schools.

\subsection{School Performance Toward Student Learning Results}

On the other hand it is also shown that school performance has a positive influence on student learning outcomes. On that basis it appears, that the performance of high or low school dormitory directly affects the quality of high or low student learning outcomes. The implication, attention to the performance of dormitory schools is a serious action that must be taken, if you want to produce quality and competitive human resources. Schools must be able to develop competent Papuan human resources, in the sense of mastering and utilizing science and technology, creative, critical thinking, collaborative, and communication.

Field findings indicate that dormitory schools still achieve learning outcomes that far exceed expectations. School performance is still not supported by adequate facilities, starting from school facilities, dormitories, number of teachers, laboratory equipment textbooks, availability of information and communication technology and the low ability of teachers to utilize, lack of opportunities for Papuan children to pursue higher education and assistance education fund. Dormitory schools in the Papua province must be able to answer the challenges of forming student competencies that are in line with the development of the 21 st century.

\section{Conclusion}

Two important notes from this study are the positive influence of government policy variables and teacher continuity commitment on dormitory school performance. The government still seems to be less consistent in implementing policies, both those related to education and non-education aspects. The first is related to the maintenance of the physical condition of school buildings, dormitories, teacher residences, and supporting facilities for other learning activities, while the second is related to the completeness of teachers and staff, the availability of dormitory managers, to the fulfillment of students' daily meals. All of them require synergic work coordination in accordance with their respective authorities and responsibilities, thus impacting on school performance.

Another variable is continuance commitment. Especially honorarium teachers, the majority of respondents tend to switch if they get a new place to work. The desire to change jobs is strengthened by the issuance of government regulation Number 49 of 2018 concerning Management of Employee Governments with Employment Agreements (PPPK). In this regulation, it is stated that it does not allow the existence of honorarium teachers, but with a minimum one-year contract (contract). The Minister of Education and Culture of the Republic of Indonesia has also stressed that schools are prohibited from recruiting honorarium teachers. Recruitment of PPPK teachers is done through objective selection based on competencies, qualifications, institutional requirements, and other requirements. Schools that have been receiving honorarium teachers whose funds are taken from the DAK / BOS program, like it or not, should encourage their teachers to take part in the PPPK selection. Schools will experience difficulties if the teacher does not pass the selection, because they have to give up work relations with the honorarium teacher, in addition to the teacher's own desire to change jobs.

On the basis of that first aid recruitment is recommended to prioritize the honorarium teacher by not implementing a system of employment agreements (contracts). The honorarium teacher does not need to undergo selection, but must take part in training held by the government for a certain period of time. After training and being declared eligible, the teacher runs a probationary period in a certain time (for example: two years). This assessment determines whether or not gurus are accepted as permanent non-ASN workers. In carrying out their work, this type of teacher has the right to get a salary / wage in accordance with applicable regulations (recommended based on regional minimum wages), the right to take competency tests to get an educator certificate and teacher professional allowance, family health services, leave rights, teaching skills improvement training, and others. This treatment can prevent the honorarium teacher's desire to leave teaching assignments and move to a new workplace. 


\section{References}

Agung, I. (2017). Competent and Professional Teachers: 21st Century Perspective. Oration of Research Professor. Jakarta: LIPI-MOEC.

Akbar, A., Musadieq, M. A., \& Mukzam, M. D. (2017). The Influence of Organizational Commitment to Performance (Study of PT PELINDO Surabaya Employees). Journal of Business Administration, 47(2), 33-38.

Anderson, J. E. (1969). Public Policy Making. New York: Holt, Rinehart and Winston.

Anwar, C. (2014). Educational System in China. Beijing: Indonesian Embassy.

Ardianto, E., \& Soemirat, S. (2010). Basics of Public Relations. Bandung: Teenager Rosdakarya.

Ashari, H. (2014). Education Budget 20\%, Has It Been Allocated? Jakarta: Ministry of Finance Education and Training Agency.

Bacal, R. (2004). How to Manage Job Performance. New York: Mc Graw-Hill Companies, Inc.

BPS. (2016). Papua Province Statistics. Jayapura: Central Bureau of Statistics of Papua Province.

Bull, V. (2001). Oxford: Learner's Pocket Dictionary (4th ed.). New York: Oxford University Press.

Bunu, H. Y. (2014). Dayak Tribe Community Awareness of Children's Education in Central Kalimantan. Educational Horizon, Th. XXXIII(33), 445-453.

Dewi, N. A. K., Zukhri, A., \& Dunia, I. K. (2014). Analysis of Factors Causing Discontinued Children of Elementary School Age in Gerokgak District in 2012/2013, 4(1), 1-12. Retrieved from http://arperpus.balikpapan.go.id/jurnal/web/pdf/PENDIDIKAN-SEKOLAH-DASAR.pdf

Dunn, W. N. (2011). Public Policy Analysis. Publisher Pearson.

Ferryanto, A., \& Hatane, S. E. (2015). Analysis of the Effect of Corporate Image on Banking Company Financial Performance in Surabaya. Business Accounting Review, 3(2), 91-100.

Foster, G. M. (1970). Traditional Society and Technological Changes. New York: Harper \& Bros.

Friedrich, C. J. (1963). Man and His Government. New York: McGraw-Hill.

Gomes, F. C. (1995). Human Resource Management. Yogyakarta: Andi Offset.

Gronroos, C. (1990). Service Management and Marketing: Managing the Moment of Truth in Service Competition. Massachusetts: Lexington.

Hair, J. F., Black, W. C., Babin, B. J., Anderson, R. E., \& Tatham, R. L. (2006). Multivariate Data Analysis (6th ed.). Prentice Hall.

Haryono, S., \& Wardoyo, P. (2013). Structural Equation Modeling (SEM) for Management Research with AMOS 18.00. Jakarta: Luxima Metro Media. https://doi.org/10.1037/0022-0663.97.1.32

Hidayat, W. (2013). The Influence of Educational Policy through the Teacher Professional Certification Program on Teacher Performance in the Learning Process in Vocational Schools in Bantul District. Yogyakarta State University.

Hong, S., \& Ho, H. Z. (2005). Direct and Indrect Longitudinal Effect of Parental Involvement on Student Achievement: Second-Orde Latent Growth Modeling Across Ethnic Eropa. Journal of Educational Psychology, 97, 32-42. Slameto. 2010. Belajar

Hulukati, W. (2015). The Role of Family Environment on Child Development. Musawa Journal, 7(2), 265-282.

Hurlock, E. B. (1980). Developmental Psychology an Approach through the Life Range. Jakarta: Erlangga.

Irwana, H. M. (2011). The Role of Children in Children's Education (Case Study of Fishermen Communities in Tasik Agung Village, Rembang District - Rembang Regency). Semarang: Semarang State University.

ISTE. (2008). National Educational Technology Standards (NETS•T) and Performance Indicators for Teachers, ISTE.

Kamsihyati, T., Sutomo, \& Sakinah, F. S. (2016). Study on Factors of School Drop-outs in Jangrana Village Kesugihan Sub-district, Cilacap District. Geo Education Journal, 5(1), 16-21.

Kepala, V. A. (2017). Parents' Aspirations in Children Education in Kimakama Village, Kec. Ile Ape, Kab Lembata Provinsi Nusa Tenggara Timur (NTT). Journal of Education Policy, 6(8), 862-875. 
Kingsley, L. H. (1951). The Nature and Conditions of Learning Hardcover. Prentice-Hall, Inc.

Kompas.com (2018). Bappenas and IASA Develop Dormitory Pattern Schools in Papua and West Papua. Jakarta, $08 / 02 / 2018$.

Kotler, P. (2011). Marketing Management. Jakarta: PT. Index.

Kraft, M. E., \& Furlong, S. R. (2017). Public Policy: Politics, Analysis, and Alternatives (6th ed.). Publisher: CQ Press.

Küçüksüleymanoğlu, R. (2017). The influence of Organizational Image on Academic Success for International Students. International Journal of Higher Education, 6(5), 56-64. https://doi.org/10.5430/ijhe.v6n5p56

Kusnendi. (2009). Structural Equation Modeling. Bandung: Alfabeta.

Kusumasitta. (2014). Relevance of Dimensions of Service Quality and Customer Satisfaction for Visitors of the Museum at Taman Mini Indonesia Indah. Journal of Management and Marketing Services, 7(1), 153-176. https://doi.org/10.25105/jmpj.v7i1.525

Latan, H. (2012). Structural Equation Modeling, Concepts and Applications Using Lisrel 8.80. Bandung: Alfabeta.

Lazear, E. P. (Ed.). (2002). Education in the Twenty-first Century. Stanford University's Graduate School of Business.

Lievens, F. (2017). Organizational Image. The Encyclopedia of Industrial and Organizational Psychology, 1116-1118. http://dx.doi.org/10.4135/9781483386874.n382

Maksudin. (2008). Dormitory School Education in SMPIT Yogyakarta. Dissertation. Sunan Kalijaga UIN.

Manullang, R. A. (2017). The Influence of Teachers Performance on Students' Learning Outcomes at State Junior High School 4 Tanjung Jabung Timur, Jambi City. Scientific Journal of Batanghari Jambi University, 17(3), 1-6.

Mathis, R. L., \& dan Jackson, J. H. (2006). Human Resource Management. Jakarta: Salemba Empat.

McKenna, T. (2002). The Loyalty Quotient. Journal National Petroleum News, 4.

Namubiru, B., Nabeta, N., Ntayi, J., \& Rulangaranga, D. M. (2014). Corporate Image and Organizational Performance of State Owned Enterprises Monitored by Privatization Unit (PU) Uganda. European Journal of Business and Management, 6(17), 235-239.

Nurandini, A., \& Lataruva, R. (2014). Influence Analysis of Organizational Commitment to Employee Performance (Study of Jakarta Public Housing Officials). Journal of Management \& Organization Studies, $11,78-91$.

Nurbiyati, T. (2014). Analysis of the Effect of Affective, Continuous and Normative Commitments on Performance with Work Discipline As Intervening Variables. Journal of Business Studies, 22(1), 21-37. https://doi.org/10.32477/jkb.v22i1.195

Nurkhamid, M. (2015). Types of Dormitory schools. Retrieved from February 8, 2019, from http://www.elib.unicom.ac.id

Nurwati, N. (2008). Effects of Family Social and Economic Conditions on the Motivation of Child Labor in Helping Families in Cirebon District, West Java. Padjadjaran Population Journal, 10(2), 112-121.

Pane, S. G., \& Fatmawati. (2017). Effect of Organizational Commitment on Employee Performance at Medan City National Land Agency. Journal of Management \& Business Research, 2(3), 67-79.

Papua Province Regional Regulation Number 2 of 2013.

Pearlman, B. (2006). $21^{\text {st }}$ Century Learning in Schools - A Case Study of New Technology High School in Napa, $C A$. New Directions for Youth Development. https://doi.org/10.1002/yd.170

Perdana, N. S. et al. (2017). Final Report of the Dormitory School Research. Jakarta: Center of Research Policy of Education and Culture. MOEC Republic of Indonesia.

Prakarsa, L. M., \& Tarigan, J. (2016). Effect of Customer Satisfaction on Financial Performance Through Customer Loyalty as Intervening Variables in Various Sector Companies in Indonesia. Business Accounting Review, 4(1), 362-372.

Purwoko, B. et al. (2015). Study of Development of Dormitory Patterned Education in Intan Jaya Regency. 
Yogyakarta: PPKK UGM.

Robbins, S. P. (1997). Essentials of Organization Behavior. New Jersey: Prentice-Hall International Inc.

Santhi, N. H., \& Hartati, W. (2017). Effect of Service Quality on Student Performance and Satisfaction (Case Study of STIA Muhammadiyah Selong Students). Humanitas Journal, 4(1), 1-15.

Saufa, J., \& Maryati, T. (2017). The Impact of Job Satisfaction in Improving Nurse's Performance with Organizational Commitment as Intervening Variables (Study of Nurses at PKU Muhammadiyah Gamping Hospital). Business Journal: Theory and Implementation, 8(2), 200-213. https://doi.org/10.18196/bti.82094

Soetjipto, B. W. (1997). Measuring Business Performance Balanced Scorecard. Businessman, Th. XXVI(6), 21-25.

Sudrajat, U. (2018). Study of dormitory schools to improve access and quality of education and strengthen social integration in the province of Papua. Center of Research Policy Education and Culture, MOEC Republic of Indonesia.

Sugiyanto, E. (2017). Factors Causing High School Drop Out Children in Bukit Lipai Village Batang Cenaku District, Inderagiri Julu District. JOM Fisip, 4(2), 1-14.

Sukendro, J., \& Pujiharjanto, J. H. (2012). The Effect of Dividend Policy on Company Performance in Indonesia (Empirical Study on Integrated Non-Financial Companies in the Indonesia Stock Exchange with Probabilistic Regression Model. C-BAM FE Unissula, 475-484.

Suryadi, A. (2012). Education, HR Investment, and Development: Issues, Theories, and Applications for the Development of Indonesian Education and Human Resources. Bandung: Widya Aksara.

Suryana, A. (2016). Effect of Policy Implementation on Banjar Family Planning and Women's Empowerment Agency Employee Performance: Study of Banjar Mayor Regulation No. 3 of 2012 concerning Establishment of Agency / Agency Technical Implementation Units in the Banjar City Government Environment, Pasundan University.

Tahya, A. H. F (2009). Dormitory schools and Islamic dormitory schools in the future. Retrieved from http://masthoni.wordpress.com/2009/06/14/dormitory-school-dan-pesantren-masa-depan/\#

Tall, D., \& Vinner, S. (1981). Concept image and concept definition in mathematics with particular reference to limits and continuity. Educational studies in mathematics, 12(2), 151-169. https://doi.org/10.1007/BF00305619

Unicef. (2016). Indonesia Annual Report 2005, Unicef. Retrieved from https://www.unicef.org/indonesia/id/Reports_Years_UNICEF_Indonesia_2015.pdf

Usman, H. (2014). Management Theory, Practice, and Educational Research. Bumi Aksara Publishing.

Utama, B. et al. (2017). Research Report on Increasing Access and Quality of Education in the Provinces of Papua and West Papua. Jakarta: Center of Research Policy of Education and Culture, MOEC Republic of Indonesia.

Zulfahmi, Yusrizal, \& Niswanto. (2017). The Effect of School Organizations and Teacher Performance on Student Learning Achievement at Bireuen District Vocational School. Journal of Educational Administration Masters, 5(2), 96-102.

\section{Copyrights}

Copyright for this article is retained by the author(s), with first publication rights granted to the journal.

This is an open-access article distributed under the terms and conditions of the Creative Commons Attribution license (http://creativecommons.org/licenses/by/4.0/). 